This is an electronic reprint of the original article. This reprint may differ from the original in pagination and typographic detail.

Author(s): Knott, Jackson P.; Hänninen, Mikko M.; Rautiainen, Mikko; Tuononen, Heikki; Hayes, Paul G.

Title: $\quad$ Insights into the decomposition pathway of a lutetium alkylamido complex via intramolecular $\mathrm{C}-\mathrm{H}$ bond activation

Year: $\quad 2017$

Version:

Please cite the original version:

Knott, J. P., Hänninen, M. M., Rautiainen, M., Tuononen, H., \& Hayes, P. G. (2017). Insights into the decomposition pathway of a lutetium alkylamido complex via intramolecular $\mathrm{C}-\mathrm{H}$ bond activation. Journal of Organometallic Chemistry, 845, 135143. https://doi.org/10.1016/j.jorganchem.2017.04.008

All material supplied via JYX is protected by copyright and other intellectual property rights, and duplication or sale of all or part of any of the repository collections is not permitted, except that material may be duplicated by you for your research use or educational purposes in electronic or print form. You must obtain permission for any other use. Electronic or print copies may not be offered, whether for sale or otherwise to anyone who is not an authorised user. 


\title{
Insights into the decomposition pathway of a lutetium alkylamido complex via intramolecular $\mathrm{C}-\mathrm{H}$ bond activation
}

\author{
Jackson P. Knotta ${ }^{\mathrm{a}}$, Mikko M. Hänninen ${ }^{\mathrm{a}, \mathrm{b}}$, J. Mikko Rautiainen ${ }^{\mathrm{b}}$, Heikki M. Tuononen ${ }^{\mathrm{b}}$, Paul G. \\ Hayes $^{\mathrm{a}, *}$
}

aDepartment of Chemistry and Biochemistry, University of Lethbridge, 4401 University Drive, Lethbridge, AB Canada, T1K 3M4

${ }^{\text {b} D e p a r t m e n t ~ o f ~ C h e m i s t r y, ~ U n i v e r s i t y ~ o f ~ J y v a ̈ s k y l a ̈, ~ P . O . ~ B o x ~ 35, ~ F I-40014, ~ J y v a ̈ s k y l a ̈, ~ F i n l a n d ~}$

\begin{abstract}
Synthesis, characterization and reaction chemistry of lutetium alkylamido $\mathbf{L L u}\left(\mathrm{CH}_{2} \mathrm{SiMe}_{3}\right)\left(\mathrm{NHCPh}_{3}\right)(\mathbf{2}), \mathbf{L}=2,5-$ $\left[\mathrm{Ph}_{2} \mathrm{P}=\mathrm{N}\left(4-{ }^{i} \mathrm{PrC}_{6} \mathrm{H}_{4}\right)\right]_{2} \mathrm{NH}\left(\mathrm{C}_{4} \mathrm{H}_{2}\right)$, is reported. Complex 2 undergoes cyclometalation of the $\mathrm{NHCPh}_{3}$ ligand at elevated temperatures to produce the orthometalated complex $\mathbf{3}, \mathbf{L L u}\left(\kappa^{2-\mathrm{N}, \mathrm{C}_{-}}\right.$ $\left.\left(\mathrm{NHCPh}_{2}\left(\mathrm{C}_{6} \mathrm{H}_{4}\right)\right)\right)$ which converts to 0.5 equivalents of bis(amido) $\mathbf{L L u}\left(\mathrm{NHCPh}_{3}\right)_{2}(\mathbf{4})$, upon heating at $80{ }^{\circ} \mathrm{C}$ for 24 hours. Reaction of complex 2 with 4-dimethylaminopyridine (DMAP) does not promote alkane elimination nor imido formation. A kinetic analysis of the thermal decomposition of complex 2 , supported by deuterium labelling studies and computational analysis (PBE0/def2$\mathrm{TZVP} / \mathrm{SDD}(\mathrm{Lu})$ ), indicate direct $\mathrm{C}_{\mathrm{sp} 2}-\mathrm{H}$ activation, rather than $\mathrm{C}-$ $\mathrm{H}$ addition across a transient $\mathrm{LLu}=\mathrm{NCPh}_{3}$ species, occurs.
\end{abstract}

Terminal imido complexes ( $\mathrm{LM}=\mathrm{NR}$ ) of transition metals and actinides have received considerable attention in recent decades because of their versatile catalytic and group transfer properties. ${ }^{1}$ The striking paucity of analogous compounds that feature a rare earth (group III and lanthanides) metal centre has prompted extensive efforts to isolate examples of this elusive class of compound.$^{2}$ Interest in this area increased in 2003 when Hessen proposed a terminal imido intermediate in the reaction of a scandium diene complex with benzonitrile. ${ }^{3}$ While that ephemeral species $\left(\mathrm{C}_{5} \mathrm{H}_{4}\left(\mathrm{CH}_{2}\right)_{2} \mathrm{~N}\left(\mathrm{CH}_{3}\right)_{2}\right) \mathrm{Sc}=\mathrm{N}\left(\mathrm{C}(\mathrm{Ph}) \mathrm{CH}_{2} \mathrm{C}(\mathrm{Me})=\mathrm{C}(\mathrm{Me}) \mathrm{CH}_{2}\right) \quad$ was neither isolated nor spectroscopically observed, Mindiola and coworkers provided compelling evidence for a transient scandium imido functionality in 2008. ${ }^{4}$ The formation of [2-P $\mathrm{Pr}_{2}-4-$ $\left.\mathrm{MeC}_{6} \mathrm{H}_{3}\right]_{2} \mathrm{NSc}=\mathrm{N}\left(2,6-{ }^{i} \mathrm{Pr}_{2} \mathrm{C}_{6} \mathrm{H}_{3}\right)\left(\mathrm{NC}_{5} \mathrm{H}_{5}\right)$ was supported by intermolecular $\mathrm{C}_{\mathrm{sp} 2}-\mathrm{H}$ bond activation of aromatic solvents and complemented by complexation with $\mathrm{Al}\left(\mathrm{CH}_{3}\right)_{3}$ to afford [2-P ${ }^{i} \mathrm{Pr}_{2}-4$ $\left.\mathrm{MeC}_{6} \mathrm{H}_{3}\right]_{2} \mathrm{NSc}=\mathrm{N}\left(2,6-{ }^{i} \mathrm{Pr}_{2} \mathrm{C}_{6} \mathrm{H}_{3}\right)\left(\mathrm{Al}\left(\mathrm{CH}_{3}\right)_{3}\right)$ in $45 \%$ yield. Subsequent work reported intriguing reaction chemistry utilizing a tautomerization process between a pyridyl-anilide complex and a pyridine-imido species, wherein various pyridine derivatives were activated and functionalized. ${ }^{5}$ Following these seminal contributions, the first structurally characterized terminal rare earth imido complex was reported by Chen et al. in $2010 .{ }^{6}$ Since then, only a handful of papers describing these exceptional compounds have been published. ${ }^{5 b, 7}$

Despite the limited amount of research performed hitherto, terminal scandium imido species have displayed remarkable reactivity with a large selection of small molecules. Notably, these complexes have been shown to transform various unsaturated compounds into useful synthetic building blocks, ${ }^{7 b, 7 g}$ in addition to readily reacting with main group fragments ${ }^{7-j}$ and transition metal complexes. ${ }^{7 \mathrm{c}}$

While impressive in their initial scope, a general mechanistic understanding of the formation of the $\mathrm{LM}=\mathrm{NR}(\mathrm{M}=\mathrm{Sc}, \mathrm{Y}, \mathrm{Lu})$ motif has not been realized. For example, alkane elimination from an alkylamido complex (resulting in an imido functionality) is not typically observed in the absence of internal or external Lewis base. ${ }^{7 \mathrm{e}, 8}$ This result was highlighted by Piers and co-workers when a scandium alkylamido complex, $\mathrm{L}_{\text {nacnac }} \mathrm{Sc}(\mathrm{NHDipp})\left(\mathrm{CH}_{3}\right), \mathrm{L}_{\text {nacnac }}=$ (DippNC $\left.\left({ }^{t} \mathrm{Bu}\right) \mathrm{CHC}\left({ }^{t} \mathrm{Bu}\right) \mathrm{NDipp}\right)$, Dipp $=2,6-{ }^{i} \mathrm{Pr}_{2} \mathrm{C}_{6} \mathrm{H}_{3}$, underwent cyclometalation of a Dipp isopropyl group upon thermolysis at 90 ${ }^{\circ} \mathrm{C}$. However, the presence of 4-dimethylaminopyridine (DMAP) was found to stimulate $\mathrm{N}-H$ bond activation, resulting in the spectroscopically characterized imido complex Lnac${ }_{\text {nac Sc}=N D i p p}($ DMAP) $){ }^{7 e}$ Furthermore, the only external Lewis bases that have proven useful for initiating imido formation have been pyridine derivatives, with DMAP being employed in the majority of structurally characterized examples. ${ }^{6,7 a, c-f,}$ Notably though, a $\beta$ diketiminato ancillary ligand bearing a tethered dimethylamino group has been demonstrated to promote imido formation under mild conditions. ${ }^{7 b, j}$ While all of the aforementioned examples are limited to scandium, it is noteworthy that Anwander recently reported terminal lutetium and yttrium imido species $\left(\mathrm{Tp}^{t \mathrm{Bu}, \mathrm{Me}}\right) \mathrm{Y}=\mathrm{N}\left(2,6-\mathrm{Me}_{2} \mathrm{C}_{6} \mathrm{H}_{3}\right)(\mathrm{DMAP}), \quad\left(\mathrm{Tp}^{t \mathrm{Bu}, \mathrm{Me}}\right) \mathrm{Lu}=\mathrm{N}(3,5-$ $\left.\left(\mathrm{CF}_{3}\right)_{2} \mathrm{C}_{6} \mathrm{H}_{3}\right)$ (DMAP)) that exhibit very short $\mathrm{M}=\mathrm{N}$ bond distances. ${ }^{9}$ Albeit a preliminary milestone, this remarkable contribution has demonstrated that the imido bonding motif is accessible for rare earth metals larger than scandium.

All isolated and spectroscopically characterized complexes of the form $\mathrm{LM}=\mathrm{NR}(\mathrm{M}=\mathrm{Sc}, \mathrm{Y}, \mathrm{Lu})$ feature an aromatic group bound to the imido nitrogen, with the most common being Dipp. Due to the linear nature of the $\mathrm{Sc}=\mathrm{NR}$ bond, overlap of the Dipp $\pi$-symmetric orbitals with the antibonding orbitals of the multiply bound NR ligand might occur, which would decrease the $\mathrm{Sc}=\mathrm{NR}$ bond order, and could thus be a contributing factor to the paucity of such compounds in the literature. With this in mind, this work utilizes a nitrogenous ligand bearing an aliphatic $\mathrm{CPh}_{3}$ moiety in lieu of a traditional aromatic substituent.

Previously, we reported a thermally stable dialkyl lutetium complex which was supported by a bis(phosphinimine)pyrrole ligand, $\mathbf{L L u}\left(\mathrm{CH}_{2} \mathrm{SiMe}_{3}\right)_{2}(\mathbf{1}), \mathbf{L}=2,5-\left[\mathrm{Ph}_{2} \mathrm{P}=\mathrm{N}\left(4-{ }^{i} \mathrm{PrC}_{6} \mathrm{H}_{4}\right)\right]_{2} \mathrm{NH}\left(\mathrm{C}_{4} \mathrm{H}_{2}\right) .{ }^{10}$ This complex has been shown to resist thermal decomposition (80 ${ }^{\circ} \mathrm{C}$ ) unlike our previously utilized bis(phosphinimine)carbazole framework. ${ }^{11,12}$ Rare earth complexes supported by the carbazole scaffold underwent spontaneous self-destructive cyclometalation at the $P$ - and $N$-bound groups of the phosphinimine donors. As such, we have chosen to employ our pyrrole-based ligand in a strategic attempt to generate a robust $\mathrm{Lu}=\mathrm{N}$ functionality. Herein, we report the synthesis and thermolysis of a lutetium imido precursor, along with deuterium labelling, kinetic and computational studies that shed light upon its observed chemical reactivity. 


\section{RESULTS AND DISCUSSION}

Scheme 1. Formation of $\mathrm{LLu}\left(\mathrm{CH}_{2} \mathrm{SiMe}_{3}\right)\left(\mathrm{NHCPh}_{3}\right)$ (2).

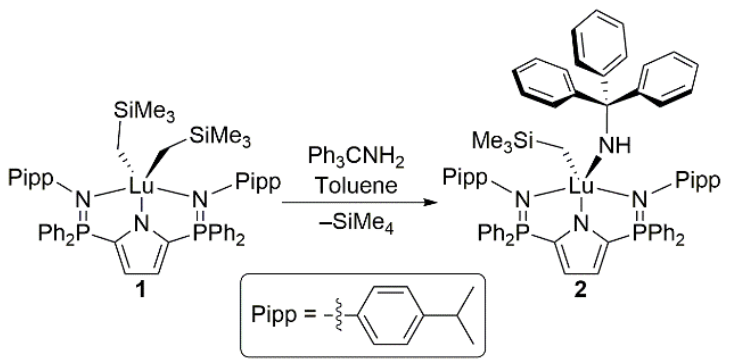

Reaction of dialkyl complex $\mathbf{L L u}\left(\mathrm{CH}_{2} \mathrm{SiMe}_{3}\right)_{2}(\mathbf{1})$ with one equivalent of $\mathrm{Ph}_{3} \mathrm{CNH}_{2}$ for one hour at ambient temperature in toluene solution afforded the desired alkylamido complex $\mathbf{L L u}\left(\mathrm{CH}_{2} \mathrm{SiMe}_{3}\right)\left(\mathrm{NHCPh}_{3}\right)(\mathbf{2})$ as a white powder isolated in $98 \%$ yield, (Scheme 1). This transformation was supported by the emergence of a new signal in the ${ }^{31} \mathrm{P}\left\{{ }^{1} \mathrm{H}\right\}$ NMR spectrum at $\delta 23.8$, along with concomitant disappearance of a resonance at $\delta 25.1$ corresponding to $\mathrm{LLu}\left(\mathrm{CH}_{2} \mathrm{SiMe}_{3}\right)_{2}$. Corroborating evidence was also observed in the ${ }^{1} \mathrm{H}$ NMR spectrum as one equivalent of $\mathrm{SiMe}_{4}(\delta$ $0.00)$ was produced in the reaction mixture. In addition, a broad singlet $(\mathrm{N}-H)$ resonating at $\delta 2.93$, which did not give rise to any cross-peaks in either the ${ }^{1} \mathrm{H}-{ }^{1} \mathrm{H}$ COSY or ${ }^{1} \mathrm{H}-{ }^{13} \mathrm{C}$ HSQC spectra, gradually appeared over the course of the reaction, eventually integrating as $1 \mathrm{H}$. Although complex $\mathbf{2}$ is thermally stable at ambient temperature as a solid for short periods it steadily decomposes in solution (even at $-35{ }^{\circ} \mathrm{C}$ ) to 0.5 equivalents of $\mathbf{L L u}\left(\mathrm{NHCPh}_{3}\right)_{2}$ (4) and several unidentified metal containing species. Hence, despite exhaustive efforts, we were unable to obtain X-ray quality crystals or analytically pure samples of complex 2 .

Scheme 2. Experimentally Observed Decomposition of Complex 2

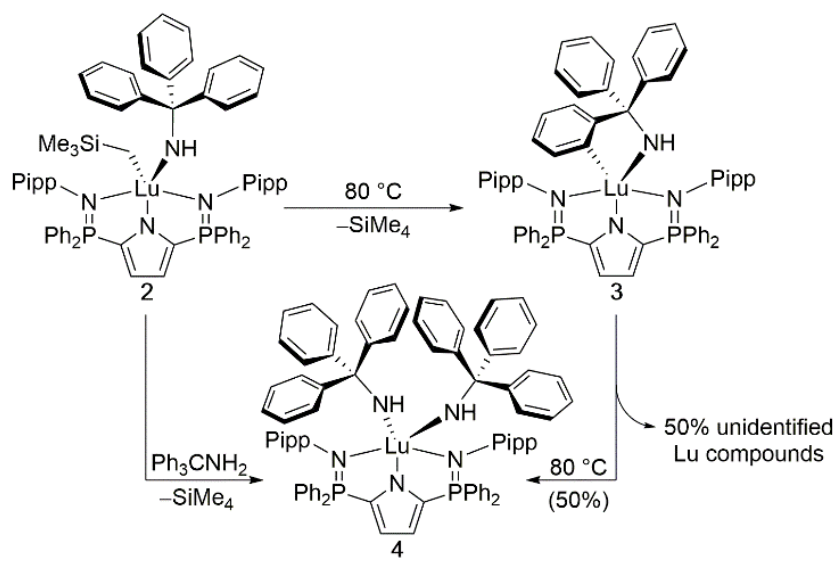

Thermolysis for 24 hours at $80{ }^{\circ} \mathrm{C}$ resulted in complete consumption of complex 2 and generation of one dominant product, complex 4, which appears as a singlet at $\delta 21.7$ in the ${ }^{31} \mathrm{P}\left\{{ }^{1} \mathrm{H}\right\}$ NMR spectrum. The formation of one equivalent of $\mathrm{SiMe}_{4}(\delta 0.00)$ and concomitant disappearance of the $\mathrm{N}-H$ signal $(\delta 2.93)$ from 2 were also observed in the ${ }^{1} \mathrm{H}$ NMR spectrum. In addition, a new singlet, which emerged at $\delta 2.70$ and integrated as $2 \mathrm{H}$, was assigned as the $\mathrm{N}-H$ of 4. Intriguingly, careful spectroscopic monitoring of this reaction revealed the formation of a reaction intermediate, $\mathbf{3}$ (vide infra), which resonates at $\delta 25.0$ in the ${ }^{31} \mathrm{P}\left\{{ }^{1} \mathrm{H}\right\}$ NMR spectra. This intermediate began converting to complex $\mathbf{4}$ before quantitative consumption of the alkylamido starting material (complex 2) was observed and, despite thorough attempts, we were unable to isolate it in pure form. In solution complex 3 exhibits spectra consistent with $\mathrm{C}_{\mathrm{s}}$ symmetry on the NMR timescale and is thus unlikely to be a metallocycle complex resulting from a single $P$-or $N$-aryl $\mathrm{C}_{\text {sp } 2}-\mathrm{H}$ bond activation, which we have previously observed with our bis(phosphinimine)carbazole ligand scaffolds (vide supra). ${ }^{11-13}$

Notably, a weak, but diagnostic resonance at $\delta 198.0$ in the ${ }^{13} \mathrm{C}\left\{{ }^{1} \mathrm{H}\right\}$ NMR spectrum is consistent with previously observed $\mathrm{C}_{\mathrm{sp} 2}$ atoms bound to lutetium, ${ }^{12-14}$ implying that complex 2 decomposes via ortho-metalation of one of the phenyl rings of the triphenylmethylamido ligand to afford cyclometalated complex $3 \mathrm{LLu}\left(\kappa^{2-\mathrm{N}, \mathrm{C}}\right.$ $\left.\left(\mathrm{NHCPh}_{2}\left(\mathrm{C}_{6} \mathrm{H}_{4}\right)\right)\right)$, (Scheme 2). Due to the similarity of the diffusion coefficient $\left(4.17(2) \times 10^{-10} \mathrm{~m}^{2} \cdot \mathrm{s}^{-1}\right)$ for complex 3 , obtained via a DOSY NMR experiment, to that of complexes $2\left(5.62(2) \times 10^{-10}\right.$ $\left.\mathrm{m}^{2} \cdot \mathrm{s}^{-1}\right)$ and $4\left(8.71(2) \times 10^{-10} \mathrm{~m}^{2} \cdot \mathrm{s}^{-1}\right)$, we have ruled out the possibility that intermediate 3 exists as a dinuclear species in solution. Notably, after decomposition of complex $\mathbf{2}$, the diamido product, complex 4, comprises only $50 \%$ of the phosphorus-containing species. Accordingly, the remaining unidentified and intractable byproducts rendered it impossible to isolate complex $\mathbf{3}$ as an analytically pure material, and is the logical source for the production of $\mathrm{Ph}_{3} \mathrm{CNH}_{2}$ needed for the formation of complex 4 (vide infra). Thus, in an effort to lend support to our spectroscopic data and corroborate the proposed identity of the $\mathrm{NCPh}_{3}$ cyclometalated $\mathbf{3}$, we undertook a computational study (vide infra) on the decomposition of alkylamido 2 .

Scheme 3. Possible Mechanisms for the Formation of Complex 3.
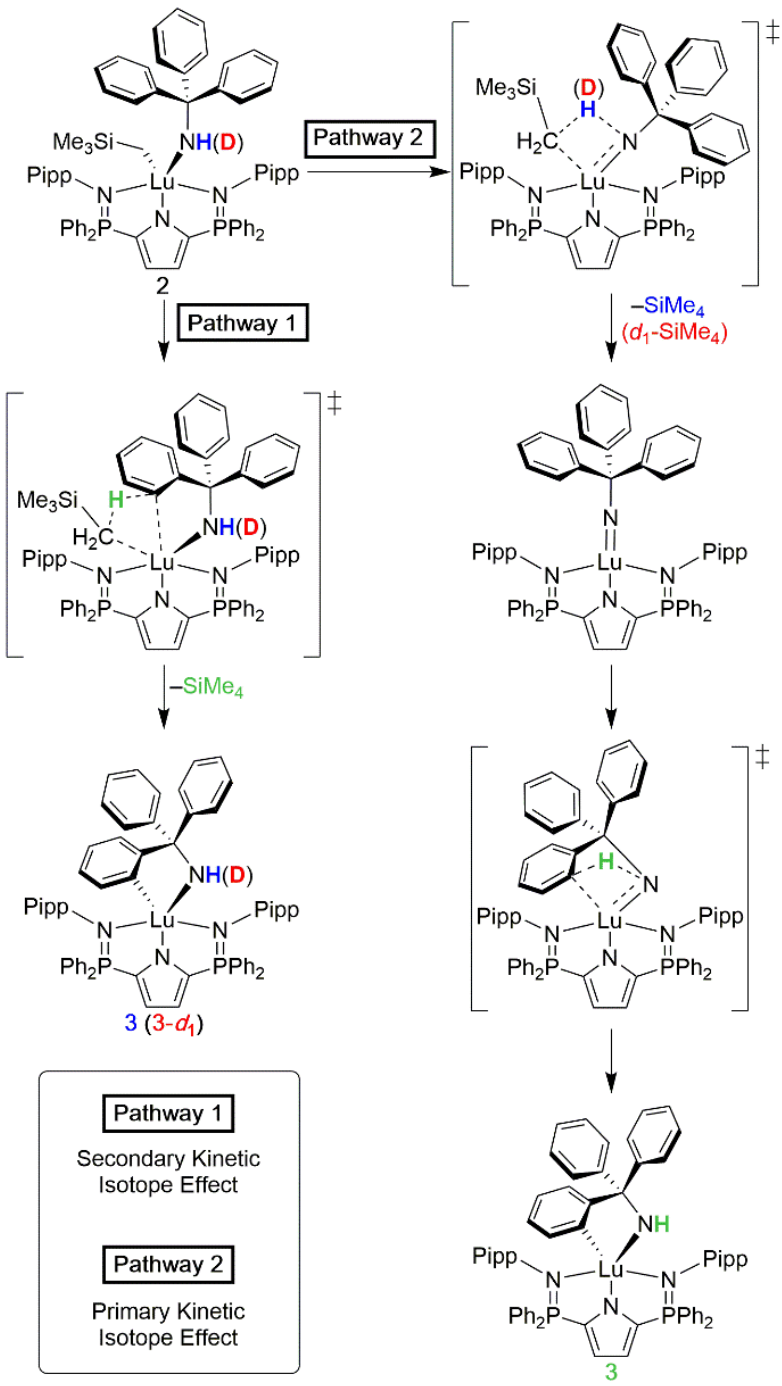

Deuterium Labelling Study

Stirring $\mathrm{Ph}_{3} \mathrm{CNH}_{2}$ with a catalytic amount of $35 \% \mathrm{DCl}$ in $\mathrm{D}_{2} \mathrm{O}$ for 10 minutes at ambient temperature proved an effective manner to 
produce $\mathrm{Ph}_{3} \mathrm{CND}_{2}$ with approximately $95 \%$ deuterium incorporation at the amine functionality. $\mathbf{L L u}\left(\mathrm{CH}_{2} \mathrm{SiMe}_{3}\right)\left(\mathrm{NDCPh}_{3}\right)\left(\mathbf{2}-\boldsymbol{d}_{\mathbf{1}}\right)$ was formed by the same synthetic procedure as that used to prepare complex 2, with the exception that a much longer reaction time (24 h vs. $1 \mathrm{~h}$ ), likely due to a large kinetic isotope effect (KIE), was required. As depicted in Scheme 3, two plausible pathways exist for the formation of complex $3: 1$ ) direct $\mathrm{C}_{\mathrm{sp} 2}-\mathrm{H}$ bond activation of the triphenylmethylamido ligand (Pathway 1); or 2) $\mathrm{N}-\mathrm{H}$ bond activation leading to a terminal imido intermediate (Pathway 2) which undergoes $\mathrm{C}_{\mathrm{sp} 2}-\mathrm{H}$ addition across the reactive $\mathrm{Lu}=\mathrm{N}$ functionality.

The thermal decomposition of complex 2 was quantitatively monitored to three half-lives over a broad range of temperatures (343 K to $373 \mathrm{~K}$ ). The reaction was established to be first order in [2] with observed rate constants ranging from $6.84(3) \times 10^{-6} \mathrm{~s}^{-1}$ to $1.38(4)$ $\times 10^{-4} \mathrm{~s}^{-1}$ for complex 2 , and $7.79(5) \times 10^{-6} \mathrm{~s}^{-1}$ to $1.63(2) \times 10^{-4}$ $\mathrm{s}^{-1}$ for $2-\boldsymbol{d}_{\boldsymbol{l}}$ (Figure 1), providing an averaged $\mathrm{kH}_{\mathrm{H}} / \mathrm{k}_{\mathrm{D}}$ of 1.3 (Table 1). This low value is consistent with a secondary KIE and would be expected if Pathway 1 were operative as the $\mathrm{N}-H(D)$ bond remains intact throughout the entire process. Additionally, no evidence for the formation of $d_{1}-\mathrm{SiMe}_{4}$, as would be the case if the reaction proceeded according to Pathway 2, was observed by either ${ }^{1} \mathrm{H}$ or ${ }^{2} \mathrm{H}$ NMR spectroscopy.

Table 1. Observed Rate Constants for the Thermal Decomposition of Complexes $\mathbf{2}$ and $\mathbf{2}-\boldsymbol{d}_{\boldsymbol{I}}$

\begin{tabular}{lccc}
\hline $\mathrm{T}(\mathrm{K})$ & $\mathrm{k}_{\mathrm{H}}\left(\mathrm{s}^{-1}\right)$ & $\mathrm{k}_{\mathrm{D}}\left(\mathrm{s}^{-1}\right)$ & $\mathrm{k}_{\mathrm{H}} / \mathrm{k}_{\mathrm{D}}$ \\
\hline 343 & $6.84(3) \times 10^{-6}$ & $7.79(5) \times 10^{-6}$ & 1.2 \\
\hline 353 & $2.32(4) \times 10^{-5}$ & $3.74(4) \times 10^{-5}$ & 1.6 \\
\hline 363 & $4.88(3) \times 10^{-5}$ & $6.44(6) \times 10^{-5}$ & 1.3 \\
\hline 373 & $1.38(4) \times 10^{-4}$ & $1.63(2) \times 10^{-4}$ & 1.2 \\
\hline
\end{tabular}

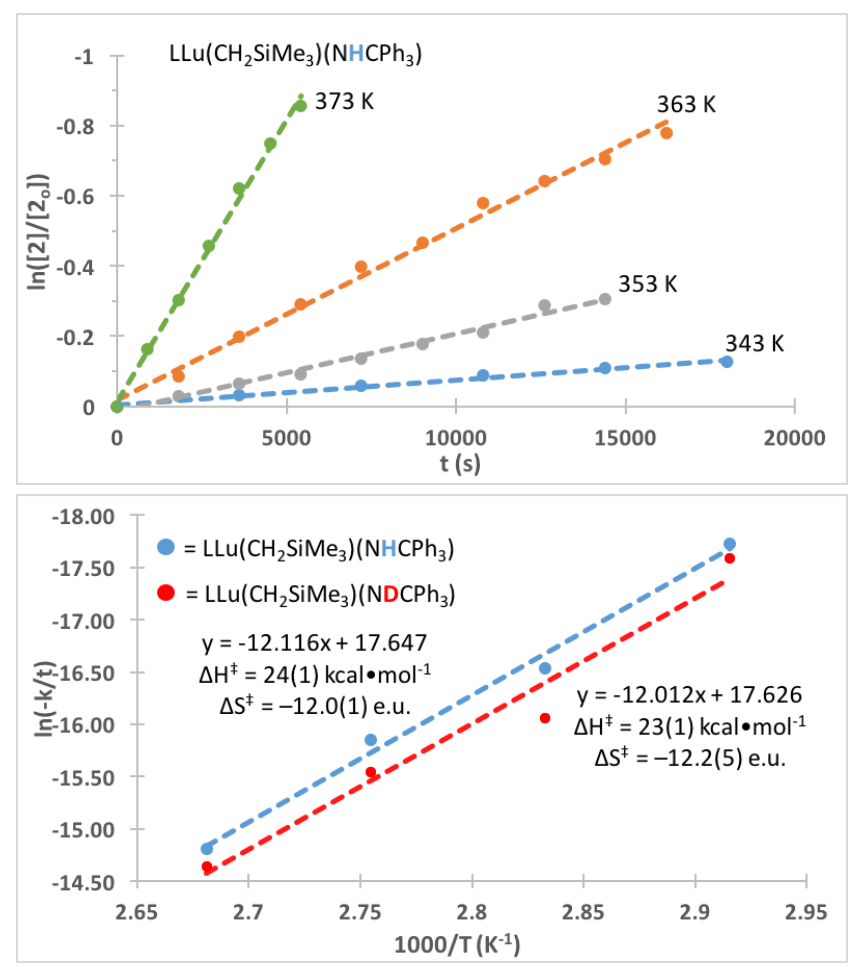

Fig 1. Top: First order plots of the thermal decomposition of complex 2 at various temperatures; Bottom: Eyring plot for the thermolysis of complexes $\mathbf{2}$ and $\mathbf{2}-\boldsymbol{d}_{\boldsymbol{I}}$
An Eyring plot was constructed from the aforementioned rate data allowing for the extraction of activation parameters $\Delta H^{\dagger}=24(1)$ $\mathrm{kcal} \cdot \mathrm{mol}^{-1}$ and $\Delta \mathrm{S}^{\dagger}=-12.0(1)$ e.u. for complex 2 and $\Delta H^{\star}=23(1)$ $\mathrm{kcal} \cdot \mathrm{mol}^{-1}$ and $\Delta \mathrm{S}^{\dagger}=-12.2(5)$ e.u. for $2-\boldsymbol{d}_{1}$ for this transformation. As expected if Pathway 1 were operative, the activation parameters for $\mathbf{2}$ and $\mathbf{2}-\boldsymbol{d}_{\boldsymbol{l}}$ are the same within experimental error. The large negative entropy of activation, which is similar to a previous examples of aryl group cyclometalation in organolutetium complexes, ${ }^{12,13}$ suggests a highly ordered transition state, consistent with a $\sigma$-bond methathesis process. Notably, these experimentally determined values closely match those determined computationally (2: $\Delta H^{\dagger}=26.4 \mathrm{kcal} \cdot \mathrm{mol}^{-1}, \Delta \mathrm{S}^{\dagger}=-15.1$ e.u.; $2-\boldsymbol{d}_{1}: \Delta H^{\dagger}=26.3$ $\mathrm{kcal} \cdot \mathrm{mol}^{-1}, \Delta \mathrm{S}^{\dagger}=-12.4$ e.u. $)$.

\section{Solid-state structure of complex 4}

Complex $\mathbf{4}$ was independently synthesized as a white solid in $77 \%$ yield by reaction of $\mathrm{LLu}\left(\mathrm{CH}_{2} \mathrm{SiMe}_{3}\right)_{2}$ with 2 equivalents of $\mathrm{Ph}_{3} \mathrm{CNH}_{2}$ in toluene solution for $22 \mathrm{~h}$ at ambient temperature. Complex 4 was recrystallized from a 5:3 toluene:heptane mixture at $35^{\circ} \mathrm{C}$ which gave colourless X-ray quality needles from which the solid-state structure was determined (Figure 2).

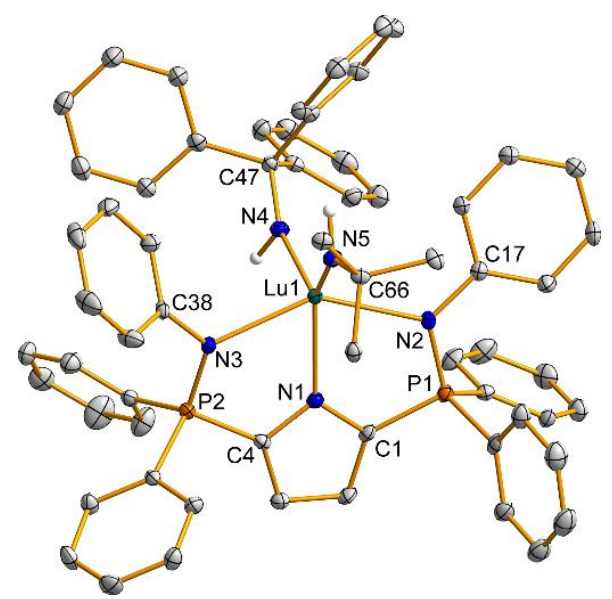

Fig. 2. Thermal ellipsoid plot (30\% probability) of complex 4 with hydrogen atoms (except amido hydrogens H4 and H5), isopropyl groups and non-ipso carbons of the $\mathrm{N} 5 \mathrm{CPh}_{3}$ group omitted for clarity.

Table 2. Selected Bond Lengths and Angles for Complex 4

\begin{tabular}{ll|ll}
\hline \multicolumn{2}{l|}{ Bond distances $(\AA)$} & \multicolumn{2}{l}{ Bond angles $\left(^{\circ}\right)$} \\
\hline Lu1-N1 & $2.293(4)$ & N1-Lu1-N4 & $107.0(1)$ \\
Lu1-N2 & $2.453(3)$ & N1-Lu1-C78 & $106.8(1)$ \\
Lu1-N3 & $2.397(3)$ & N2-Lu1-N3 & $143.7(1)$ \\
Lu1-N4 & $2.144(4)$ & N4-Lu1-N5 & $118.3(1)$ \\
Lu1-N5 & $2.143(3)$ & P1-N2-C17 & $118.9(3)$ \\
P1-N2 & $1.620(4)$ & P2-N3-C38 & $121.3(3)$ \\
P2-N3 & $1.599(4)$ & & \\
\hline
\end{tabular}

Complex 4, which crystallized in the triclinic $P-1$ space group, exhibits a coordination environment about lutetium that is best described as distorted square pyramidal $\left(\tau_{5}=0.16\right)$. The ancillary $N N N$-pincer ligand $(\mathbf{L})$ is coordinated in a planar fashion, occupying three of the pyramid base sites. The remaining base position is filled by one of the bulky triphenylmethylamido ligands (N5). Selected bond lengths and angles are reported in Table 2. At 2.453(3) and 2.397(3) the respective $\mathrm{Lu}-\mathrm{N} 2$ and $\mathrm{Lu}-\mathrm{N} 3$ bond distances are 
slightly longer than those found in complex 1 [2.364(2) and 2.332(3)], likely as a consequence of the sterically demanding amido groups. All other geometrical parameters closely match those of dialkyl 1. ${ }^{10}$ Interestingly, the Lu-N4 and Lu-N5 bonds lengths of 2.144(4) and 2.143(3) $\AA$, respectively, are similar to other $\mathrm{Lu}-$ NHR distances and slightly shorter than the average $\mathrm{Lu}-\mathrm{NHAr}$ bond length $(2.194 \AA),{ }^{15}$ which is supportive of our hypothesis that amido ligands bearing aliphatic substituents may form stronger $\mathrm{Lu}-\mathrm{N}$ bonds than their aromatic counterparts. This difference is even more striking when one considers the great steric demand imparted by the bulky $\mathrm{CPh}_{3}$ groups.

\section{Reactivity of complex 2 with 4-dimethylaminopyridine (DMAP)}

Since the presence of a Lewis base appears to be a key factor in generating terminal imido species from the requisite alkylamido complexes, we explored the reaction chemistry of complex 2 with varying stoichiometries of DMAP. Over the course of $24 \mathrm{~h}$ at ambient temperature, a slow reaction between 2 and 1 equivalent of DMAP led to the formation of 0.5 equivalents of bisamide $\mathbf{4}$, as well as unidentified contaminants, similar to the decomposition of complex 2 in the absence of DMAP. When the reactants were heated at $80^{\circ} \mathrm{C}$ for $24 \mathrm{~h}$, an intractable mixture containing a significant proportion ( $46 \%$ ) of complex 4 was obtained. Upon repeating the experiment $\left(80^{\circ} \mathrm{C}\right.$ for $24 \mathrm{~h}$ ) using an excess (4 equivalents) of DMAP a slightly broader distribution of undisclosed products prevailed, but complex 4 remained the predominant species (25\%). The analogous substoichiometric reaction ( 0.5 equivalents of DMAP) also resulted in the production of $\mathrm{LLu}\left(\mathrm{NHCPh}_{3}\right)_{2}$, albeit at a notably retarded rate. In order to reach completion, the reaction had to be heated at $70{ }^{\circ} \mathrm{C}$ for $168 \mathrm{~h}$.

The mechanism for the formation of $\mathbf{4}$ (from complex $\mathbf{2}$ ) in the presence of DMAP remains unknown. While a ligand redistribution process may seem plausible, at no point during the reaction was the thermally robust dialkyl $\mathbf{L L u}\left(\mathrm{CH}_{2} \mathrm{SiMe}_{3}\right)_{2}$ (or $\left.\mathbf{L L u}=\mathrm{NCPh}_{3}\right)$ observed by either ${ }^{1} \mathrm{H}$ or ${ }^{31} \mathrm{P}$ NMR spectroscopy. Similarly, no direct evidence for the formation of complex $\mathbf{3}, \quad \mathbf{L L u}\left(\kappa^{2-\mathrm{N}, \mathrm{C}}\right.$ $\left.\left(\mathrm{NHCPh}_{2}\left(\mathrm{C}_{6} \mathrm{H}_{4}\right)\right)\right)$, was obtained throughout the duration of the reaction. However, given that ${ }^{1} \mathrm{H}$ NMR spectroscopy indicated the liberation of $\mathrm{SiMe}_{4}(\delta 0.00)$, it is conceivable that the orthometalated compound $\mathbf{3}$ formed, only to rapidly decompose into a myriad of products in the presence of DMAP.

\section{Computational studies}

As mentioned previously, we have been unable to isolate intermediate $\mathbf{3}$ as a pure compound; hence, it seemed prudent to corroborate our experimental data with computational studies. To alleviate computational demand we have truncated our system such that $P$ phenyl groups have been replaced with methyl substituents and 4${ }^{i} \mathrm{PrC}_{6} \mathrm{H}_{4}$ (Pipp) with phenyl. Preliminary mapping of decomposition routes was performed with potential energy surface (PES) scans at the PBE0/SVP/SDD $(\mathrm{Lu})$ level. Final transition state and intermediate structures have been calculated at the PBE0/def2$\mathrm{TZVP} / \mathrm{SDD}(\mathrm{Lu})$ level of theory.

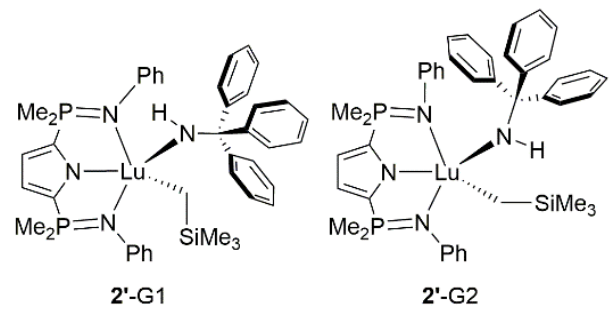

Fig 3. Calculated conformers for 2'.

Since the solid state structure of complex 2 (i.e. an X-ray crystal structure) was not available, work initiated with construction of a conformation based upon the solid-state geometry of complex $\mathbf{4}$, wherein one of the $\mathrm{NHCPh}_{3}$ ligands was substituted with a $\mathrm{CH}_{2} \mathrm{SiMe}_{3}$ group. Notably, this procedure yielded two conformers, 2'-G1 and 2'-G2, that can interconvert by rotation of the amido and alkyl groups about the $\mathrm{Lu}-\mathrm{N}$ and $\mathrm{Lu}-\mathrm{C}$ bonds, respectively (Figure 3 ). The distinguishing difference between the two structures is the proximity of the $\mathrm{CPh}_{3}$ groups to the lutetium centre. According to calculations, the shortest distance from a $\mathrm{C}_{\mathrm{sp} 2}-\mathrm{H}$ to the $\mathrm{CH}_{2} \mathrm{SiMe}_{3}$ methylene carbon in $\mathbf{2}^{\prime}$-G1 is only $3.282 \AA$, whereas in $\mathbf{2}^{\prime}$-G2 the corresponding distance is $4.481 \AA$. Hence, it is reasonable to expect that $\mathbf{2}^{2}-\mathrm{G} 1$ is more prone to $\mathrm{C}-\mathrm{H}$ bond activation and cyclometalation. Furthermore, calculations indicate that $\mathbf{2}^{\prime}-\mathrm{G} 1$ is approximately $1.5 \mathrm{kcal} \cdot \mathrm{mol}^{-1}$ lower in energy than $\mathbf{2}^{\prime}$-G2. Given the similarity of the energies of the $\mathbf{2}^{\prime}$ conformations and their structural relationship, 2'-G1 has been used in the following analysis as a starting point for decompositions routes.

PES scans of pathway 1 for the formation of $\mathbf{3}^{\prime}$ from $\mathbf{2}^{\prime}$-G1, combined with subsequent optimizations, suggested a plausible sevencoordinate stationary point structure corresponding to the transition state. The identity of the stationary point as the sought-after transition state (2'-TS) was confirmed by the sole imaginary vibration ($1221 \mathrm{~cm}^{-1}$ ) corresponding to the proton transfer from an aromatic carbon to the methylene carbon. The overall reaction energy profile is presented in Figure 4. According to the calculations, the reaction is endothermic $\left(\Delta H=9.0 \mathrm{kcal} \cdot \mathrm{mol}^{-1}\right)$ but slightly exergonic $(\Delta G=$ $\left.-0.9 \mathrm{kcal} \cdot \mathrm{mol}^{-1}\right)$ with an activation barrier of $\Delta \mathrm{G}^{\ddagger}=30.9 \mathrm{kcal} \cdot \mathrm{mol}^{-}$ 1 . These results agree well with the experimental observation that cyclometalation of $\mathbf{2}$ only proceeds to completion after a prolonged period $(24 \mathrm{~h})$ at high temperature $\left(80^{\circ} \mathrm{C}\right)$. The insignificant energy difference (within the error for computations) for the transition state with proteo and deuterated amide ligands also support the small KIE observed experimentally (vide supra).

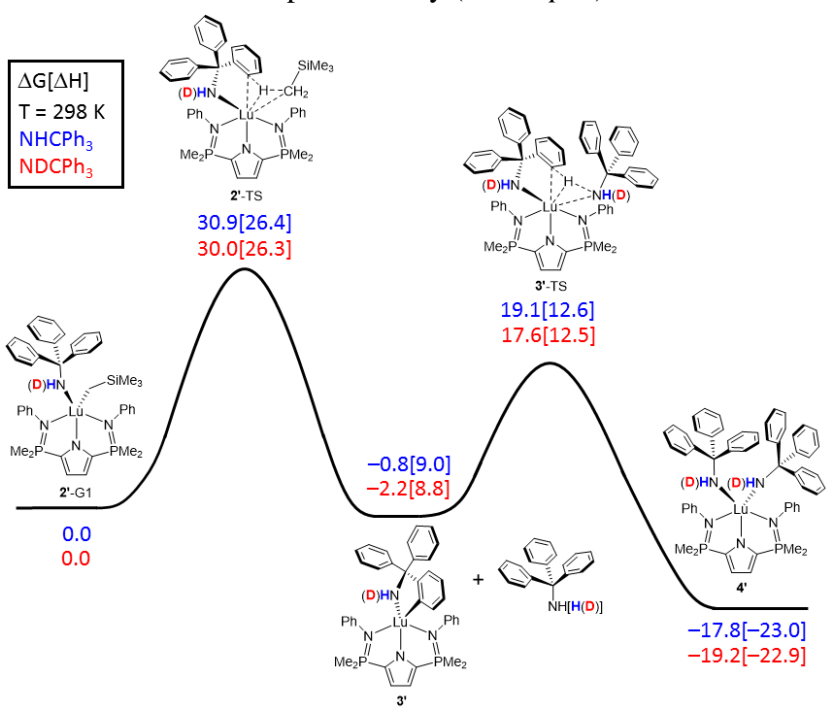

Fig. 4. Energy profile $\left(\mathrm{kcal} \cdot \mathrm{mol}^{-1}\right)$ of the cyclometalation and subsequent decomposition of complex 2'-G1.

The optimized geometry of $\mathbf{3}^{\prime}$ is presented in Figure 5. The coordination sphere about lutetium consists of the three nitrogen atoms of the bis(phosphinimine)pyrrole ligand (N1, N2 and N3), the amido nitrogen (N4) and the cyclometalated aromatic carbon $(\mathrm{C} 1)$. The coordination geometry is best described as distorted trigonal bipyramidal $\left(\tau_{5}=0.63\right)$, and the geometrical parameters are in good agreement with both the solid-state structure of complex 1 and previously reported cyclometalated lutetium complexes. ${ }^{12-14}$ For example, $\mathrm{Lu}-\mathrm{C}$ bond lengths of seven different structures with similar cyclometalated aromatic groups range from 2.337 to $2.478 \AA{ }^{13,14,16}$ in the geometry optimized $3^{\prime}$ this distance is $2.363 \AA$. Furthermore, 
the Lu1-C1-C2 (see Figure 5) bond angle of $110.8^{\circ}$ also corresponds well with experimental values $\left(106.9-117.1^{\circ}\right) .{ }^{12-14,17}$

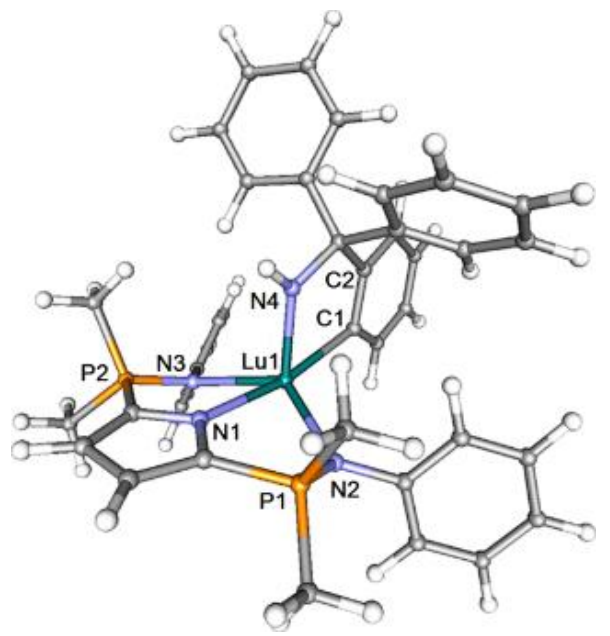

Fig. 5. Structure of $\mathbf{3}^{\prime}$ optimized at the PBE0/def2-TZVP/SDD(Lu) level. Selected bond distances $(\AA)$ and angles $\left({ }^{\circ}\right)$ : Lu1-C1 $=2.363$, Lu1-N1 $=2.344$, Lu1-N2 $=2.362$, Lu1-N3 = 2.374, Lu1-N4 = 2.104; Lu1-C1-C2 = 110.8, N1-Lu1-C1 = 168.1, N1-Lu1-N4 = 92.9, N2-Lu1-N3 = 130.4.

The second phase of the decomposition reaction of complex 2 involves formation of the bisamido species 4 (Figure 5). Various routes for the formation of complex $\mathbf{4}$, such as ligand redistribution and further metalation of $\mathbf{3}$, could be considered. Preliminary calculations using the smaller basis set, PBE0/SVP/SDD(Lu), indicated that $\mathbf{3}^{\prime}$ is amendable to dimerization. Given that ligand redistribution would be required to liberate the free amine $\left(\mathrm{Ph}_{3} \mathrm{CNH}_{2}\right)$ essential for the formation of complex $4, \mathrm{LLu}\left(\mathrm{NHCPh}_{3}\right)_{2}$, further metalation of the $P$-or $N$-aryl substituents of the bis(phosphinimine)pyrrole ligand and subsequent formation of higher nuclearity species, as observed previously with this type of ligand, is a likely necessity. ${ }^{11-12}$ Such a species is the most likely intermediate and/or side product in any reaction releasing $\mathrm{Ph}_{3} \mathrm{CNH}_{2}$. However, due to the size of these systems we were unable to determine energetics for this type of reactivity as the used computational facilities do not allow for the imperative high-level reaction energy calculations needed for such large systems (more than 200 atoms). Because of this practical restriction we concentrated our efforts upon estimating the last energy barrier for the formation of complex 4 . The process was hypothesized to proceed through a metallacycle ringopening process by reaction with an equivalent of free $\mathrm{Ph}_{3} \mathrm{CNH}_{2}$ (vide supra), as this kind of reactivity has already been observed for related Lu complexes. ${ }^{13}$ Calculation of a transition state for the direct reaction of triphenylmethylamine and $\mathbf{3}^{\prime}$ suggests that the activation barrier $\left(\Delta G^{\ddagger}=19.1 \mathrm{kcal} \cdot \mathrm{mol}^{-1}\right)$ for the formation of $\mathbf{4}^{\prime}$ from $\mathbf{3}^{\prime}$ is notably lower than the barrier for the preceding cyclometallation reaction $\left(\Delta G^{*}=30.9 \mathrm{kcal} \cdot \mathrm{mol}^{-1}\right)$. The lower activation barrier for this second step could explain the experimental difficulties associated with isolating intermediate $\mathbf{3}$, as well as the fact that considerable quantities of complex $\mathbf{4}$ are formed even before all of starting material $\mathbf{2}$ is completely consumed. Furthermore, the highly exergonic reaction energy $\left(\Delta G=-17.8 \mathrm{kcal} \cdot \mathrm{mol}^{-1}\right)$ supports this mechanism for formation of 4 .

\section{Conclusions}

In summary, we have prepared a new lutetium complex, $\mathbf{L L u}\left(\mathrm{CH}_{2} \mathrm{SiMe}_{3}\right)\left(\mathrm{NHCPh}_{3}\right)(\mathbf{2})$ and studied its thermal decomposition, in the presence and absence of DMAP. Although it was anticipated that the aliphatic $\mathrm{CPh}_{3}$ group on the amido nitrogen would encourage loss of $\mathrm{SiMe}_{4}$, along with concomitant formation of the imido complex $\mathbf{L L u}=\mathrm{NCPh}_{3}$, the phenyl substituents proved to be prone to $\mathrm{C}-\mathrm{H}$ activation, affording orthometalated $\mathbf{L L u}\left(\kappa^{2-\mathrm{N}, \mathrm{C}_{-}}\right.$
$\left.\left(\mathrm{NHCPh}_{2}\left(\mathrm{C}_{6} \mathrm{H}_{4}\right)\right)\right)(3)$. Kinetic, deuterium labelling and computational studies indicated that the putative imido species was not a transient intermediate en route to complex 3. Accordingly, future endeavours to solicit formation of a lutetium imido functionality will target cyclometalation-resistant alkylamido starting materials. In this vein, preliminary evidence suggests that replacing the electron withdrawing $\mathrm{P}-P h_{2}$ groups with donating $\mathrm{P}-{ }^{i} \mathrm{Pr}_{2}$ moieties dramatically enhances the thermal stability of analogous lutetium alkyamido complexes. Current efforts are underway to fully explore the reaction chemistry of such molecules.

\section{Experimental details}

Manipulation of air- and moisture-sensitive materials and reagents was carried out under an argon atmosphere using vacuum line techniques or in an MBraun glove box. Solvents used for air-sensitive materials were purified using an MBraun solvent purification system (SPS), stored in PTFE-sealed glass vessels over "titanocene" (pentane, benzene, and toluene), and freshly distilled at the time of use. Benzene- $d_{6}$ was dried over sodium benzophenone ketyl, degassed via three freeze-pump-thaw cycles, distilled in vacuo and stored over $4 \AA$ molecular sieves in glass bombs under argon. Unless noted, all NMR spectra were recorded at ambient temperature with a Bruker Avance II NMR spectrometer $\left(300.13 \mathrm{MHz}\right.$ for ${ }^{1} \mathrm{H}$, $75.47 \mathrm{MHz}$ for ${ }^{13} \mathrm{C}$, and $121.48 \mathrm{MHz}$ for ${ }^{31} \mathrm{P}$ ). Chemical shifts are reported in parts per million relative to the external standards $\mathrm{SiMe}_{4}$ $\left({ }^{1} \mathrm{H},{ }^{13} \mathrm{C}\right)$ and $85 \% \mathrm{H}_{3} \mathrm{PO}_{4}\left({ }^{31} \mathrm{P}\right)$; residual $\mathrm{H}$-containing species in $\mathrm{C}_{6} \mathrm{D}_{6}\left(\delta 7.16\left({ }^{1} \mathrm{H}\right), \delta 128.39\left({ }^{13} \mathrm{C}\right)\right)$ were used as internal references. Assignments were aided by the use of ${ }^{13} \mathrm{C}\left\{{ }^{1} \mathrm{H}\right\}$-DEPT-90, ${ }^{13} \mathrm{C}\left\{{ }^{1} \mathrm{H}\right\}$-DEPT-135, ${ }^{1} \mathrm{H}-{ }^{13} \mathrm{C}\left\{{ }^{1} \mathrm{H}\right\}-\mathrm{HSQC}$, and ${ }^{1} \mathrm{H}-{ }^{1} \mathrm{H}-\mathrm{COSY}$ experiments $(\mathrm{s}=$ singlet, $\mathrm{d}=$ doublet, $\mathrm{t}=$ triplet, $\mathrm{q}=$ quartet, $\mathrm{sp}=$ septet, $\mathrm{m}=$ multiplet, $\mathrm{br}=$ broad, ov $=$ overlapping signals). Elemental analyses were performed using an Elementar Vario Microcube instrument. The reagents $\mathrm{Lu}_{(}\left(\mathrm{CH}_{2} \mathrm{SiMe}_{3}\right)_{3}(\mathrm{THF})_{2}$, $\mathbf{L L u}\left(\mathrm{CH}_{2} \mathrm{SiMe}_{3}\right)_{2}$ (1) and 2,5-[ $\left.\mathrm{Ph}_{2} \mathrm{P}=\mathrm{N}\left(4-{ }^{i} \mathrm{PrC}_{6} \mathrm{H}_{4}\right)\right]_{2} \mathrm{NH}\left(\mathrm{C}_{4} \mathrm{H}_{2}\right)$ (HL), were prepared according to literature methods. ${ }^{18} \mathrm{~A}$ solid sample of $\mathrm{LiCH}_{2} \mathrm{SiMe}_{3}$ was obtained by removal of pentane from a 1.0 M solution purchased from Sigma-Aldrich. A sample of 6.0 $\mathrm{M} \mathrm{HCl}$ was prepared by dilution of a concentrated solution. All other reagents were purchased from commercial sources and used as received. $\mathrm{Ph}_{3} \mathrm{CND}_{2}$ was prepared by stirring $\mathrm{Ph}_{3} \mathrm{CNH}_{2}$ in $\mathrm{D}_{2} \mathrm{O}$ with a catalytic amount $(\sim 10 \%)$ of $\mathrm{DCl}\left(35 \%\right.$ w/w in $\left.\mathrm{D}_{2} \mathrm{O}\right)$ for 10 min. Unless otherwise specified, reported yields correspond to those obtained for analytically pure samples. When additional purification was required to generate analytically pure compounds for combustion analysis, both the crude and analytical yields are included. In such cases, the reported crude yield corresponds to material that was utilized for successive synthetic steps, and was $>98 \%$ pure as indicated by multinuclear NMR spectroscopy. (N.B. NMR spectra displayed in the ESI were obtained using these "crude" samples.) It should also be noted that when reported, analytical yields are generally artificially low, as excess crystals grown for X-ray diffraction experiments are used for this purpose. Those recrystallizations were not carried out under conditions that maximized yield, but rather, were optimized for the growth of X-ray quality crystals.

$\mathbf{L L u}\left(\mathrm{CH}_{2} \mathrm{SiMe}_{3}\right)\left(\mathrm{NHCPh}_{3}\right)$ (2). In an argon atmosphere glove box, $\mathbf{L L u}\left(\mathrm{CH}_{2} \mathrm{SiMe}_{3}\right)_{2}$ (1) (263 $\mathrm{mg}, 0.250 \mathrm{mmol}$ ) was weighed into a $20 \mathrm{~mL}$ scintillation vial and dissolved in $2 \mathrm{~mL}$ of benzene. $\mathrm{Ph}_{3} \mathrm{CNH}_{2}$ (63.5 mg, $\left.0.245 \mathrm{mmol}\right)$ was weighed into another vial and dissolved in $3 \mathrm{~mL}$ of benzene. The $\mathrm{Ph}_{3} \mathrm{CNH}_{2}$ solution was added dropwise over 5 minutes into the benzene solution of $\mathrm{LLu}\left(\mathrm{CH}_{2} \mathrm{SiMe}_{3}\right)_{2}$. The resulting colourless mixture was stirred for 1 hour at ambient temperature at which point the benzene solvent was removed in vacuo to yield an off-white oily solid. The solid was triturated 3 times with $3 \mathrm{~mL}$ of pentane, followed by 3 times with $3 \mathrm{~mL}$ of heptane, and dried under reduced pressure to yield a white powder $\left(297.0 \mathrm{mg}, 98 \%\right.$ (crude)). ${ }^{1} \mathrm{H}$ NMR (benzene- $\left.d_{6}\right): \delta$ 
7.55 (ov m, 8H, o-phenyl $H$ ), 7.51 (ov m, 4H, $m$-Pipp $H$ ), 6.96-6.94 (ov m, $31 \mathrm{H}, o$-Pipp $H$ (4), $m$ - and $p$ - phenyl $H(12), m$-, $p$ - and $o$ phenyl $\left.\mathrm{CPh}_{3} H(15)\right), 6.67\left(\mathrm{dd},{ }^{3} J_{\mathrm{H}-\mathrm{P}}=2.1 \mathrm{~Hz},{ }^{4} J_{\mathrm{H}-\mathrm{P}}=0.6 \mathrm{~Hz}, 2 \mathrm{H}\right.$, pyrrole $H), 2.93(\mathrm{~s}, 1 \mathrm{H}, \mathrm{N} H), 2.73\left(\mathrm{sp},{ }^{3} J_{\mathrm{H}-\mathrm{H}}=6.9 \mathrm{~Hz}, 2 \mathrm{H}\right.$, $\left.\mathrm{CH}\left(\mathrm{CH}_{3}\right)_{2}\right), 1.18\left(\mathrm{~d},{ }^{3} \mathrm{~J}_{\mathrm{H}-\mathrm{H}}=6.9 \mathrm{~Hz}, 12 \mathrm{H}, \mathrm{CH}\left(\mathrm{CH}_{3}\right)_{2}\right), 0.16(\mathrm{~s}, 9 \mathrm{H}$, $\left.\mathrm{Si}\left(\mathrm{CH}_{3}\right)_{3}\right),-0.23\left(\mathrm{~d},{ }^{3} \mathrm{~J}_{\mathrm{H}-\mathrm{Y}}=2.8 \mathrm{~Hz}, 2 \mathrm{H}, \mathrm{CH}_{2}\right) .{ }^{13} \mathrm{C}\left\{{ }^{1} \mathrm{H}\right\} \mathrm{NMR}$ (benzene- $d_{6}$ ): $\delta 154.7$ (s, aromatic ipso- $\left.C, \mathrm{CPh}_{3}\right), 144.1\left(\mathrm{~d},{ }^{2} J_{\mathrm{C}-\mathrm{P}}=4.9\right.$ $\mathrm{Hz}$, aromatic ipso- $C$, Pipp), 143.3 (s, aromatic ipso- $C, \mathrm{Ph}), 133.7$ $\left(\mathrm{d},{ }^{2} J_{\mathrm{C}-\mathrm{P}}=25.8 \mathrm{~Hz}\right.$, aromatic $C \mathrm{H}, o-\mathrm{Ph}$ ), 133.0 (s, aromatic ipso- $C$, p-Pipp), 132.6 (s, aromatic $C H, o$-Pipp), 132.2 (s, aromatic $C H, p$ $\mathrm{Ph}), 131.8$ (s, aromatic ipso- $C$, pyrrole), 130.5 (s, aromatic ipso- $C$ ), 129.6 (s, aromatic $\mathrm{CH}, o-\mathrm{Ph} \mathrm{CPh}_{3}$ ), 128.6 (s, aromatic $C \mathrm{H}, p-\mathrm{Ph}$ $\mathrm{CPh}_{3}$ ), 128.0 (s, aromatic $C \mathrm{H}, m-\mathrm{Ph} \mathrm{CPh}_{3}$ ), 127.5 (s, aromatic $\mathrm{CH}$, $o$-Pipp), 126.0 (s, aromatic $C H$, $m$-Pipp), 119.3 (dd, ${ }^{2} J_{\mathrm{C}-\mathrm{P}}=29.5$ $\mathrm{Hz},{ }^{3} J_{\mathrm{C}-\mathrm{P}}=11.0 \mathrm{~Hz}$, pyrrole $\left.\mathrm{CH}\right), 75.3\left(\mathrm{~s}, \mathrm{Ph}_{3} \mathrm{CNH}\right), 37.0(\mathrm{~s}, \mathrm{Lu}-$ $\left.\mathrm{CH}_{2}\right), 34.2$ (s, $\left.\mathrm{CH}\left(\mathrm{CH}_{3}\right)_{2}\right), 24.7$, (s, $\left.\mathrm{CH}\left(\mathrm{CH}_{3}\right)_{2}\right), 5.1$ (s, $\left.\mathrm{Si}\left(\mathrm{CH}_{3}\right)_{3}\right)$. ${ }^{31} \mathrm{P}\left\{{ }^{1} \mathrm{H}\right\}$ NMR (benzene- $\left.d_{6}\right): \delta 23.8$ (s). Anal. Calcd. (\%) for $\mathrm{C}_{70} \mathrm{H}_{75} \mathrm{LuN}_{4} \mathrm{P} 2 \mathrm{Si}: \mathrm{C}, 67.95 ; \mathrm{H}, 6.11 ; \mathrm{N}, 4.53$. Found: C, 66.40; H, $5.12 ; \mathrm{N}, 5.85$.

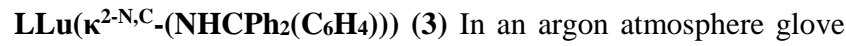
box, $\mathrm{LLu}\left(\mathrm{CH}_{2} \mathrm{SiMe}_{3}\right)\left(\mathrm{CPh}_{3} \mathrm{NH}\right)(25.3 \mathrm{mg}, 0.0207 \mathrm{mmol})$ was weighed into a $J$-Young tube and dissolved in $0.5 \mathrm{~mL}$ of benzene$d_{6}$. The resulting solution was heated at $80^{\circ} \mathrm{C}$ for 24 hours resulting in a pale yellow solution. ${ }^{1} \mathrm{H}$ NMR (benzene- $d_{6}$ ): $\delta$ 7.62-7.46 (ov $\mathrm{m}, 13 \mathrm{H}, o$-phenyl $H(8)+o$-Phenyl $\left.\mathrm{CPh}_{3} H(5)\right), 7.33\left(\mathrm{dd},{ }^{3} J_{\mathrm{H}-\mathrm{H}}=\right.$ $6.6 \mathrm{~Hz},{ }^{4} J_{\mathrm{H}-\mathrm{P}}=3.3 \mathrm{~Hz}, 4 \mathrm{H}, o$-Pipp $H$ ), $6.98-6.48$ (ov m, $25 \mathrm{H}, \mathrm{m}$ and $p$-phenyl $H$ (Pipp, $\mathrm{PPh}_{2}$ and $\left.\mathrm{CPh}_{3}\right)+m$-Pipp $\left.H\right), 6.61\left(\mathrm{~d},{ }^{3} J_{\mathrm{H}-\mathrm{P}}\right.$ $=2.1 \mathrm{~Hz}, 2 \mathrm{H}$, pyrrole $H), 3.35(\mathrm{~s}, 1 \mathrm{H}, \mathrm{N} H), 2.73\left(\mathrm{sp},{ }^{3} J_{\mathrm{H}-\mathrm{H}}=6.9\right.$ $\left.\mathrm{Hz}, 2 \mathrm{H}, \mathrm{CH}\left(\mathrm{CH}_{3}\right)_{2}\right), 1.18\left(\mathrm{~d},{ }^{3} \mathrm{~J}_{\mathrm{H}-\mathrm{H}}=6.9 \mathrm{~Hz}, 12 \mathrm{H}, \mathrm{CH}\left(\mathrm{CH}_{3}\right)_{2}\right)$. ${ }^{13} \mathrm{C}\left\{{ }^{1} \mathrm{H}\right\}$ NMR (benzene- $d_{6}$ ): $\delta 198.0$ (s, aromatic C, Lu-C), 154.9 (s, aromatic ipso- $\left.C, \mathrm{CPh}_{3}\right), 154.9$ (s, aromatic ipso- $\left.C, \mathrm{CPh}_{3}\right), 144.5$ (d, ${ }^{1} J_{\mathrm{C}-\mathrm{P}}=5.8 \mathrm{~Hz}$, aromatic ipso- $C$, Pipp), 142.4 (s, aromatic ipso$C, \mathrm{Ph}), 134.1\left(\mathrm{~d},{ }^{2} J_{\mathrm{C}-\mathrm{P}}=10.6 \mathrm{~Hz}\right.$, aromatic $\left.C \mathrm{H}, o-\mathrm{Ph}\right), 133.8(\mathrm{~d}$, ${ }^{2} J_{\mathrm{C}-\mathrm{P}}=11.1 \mathrm{~Hz}$, aromatic $C \mathrm{H}, o-\mathrm{Ph}$ ), 132.4 (s, aromatic ipso- $C, p$ Pipp), 130.9 (dd, ${ }^{1} J_{\mathrm{C}-\mathrm{P}}=90.7 \mathrm{~Hz},{ }^{3} J_{\mathrm{C}-\mathrm{P}}=6.9 \mathrm{~Hz}$, aromatic ipso- $C$, pyrrole), 129.5 (s, aromatic $C \mathrm{H}, o-\mathrm{Ph} \mathrm{CPh}_{3}$ ), 129.0-128.7 (ov m, aromatic $\mathrm{CH}, o-, p$ - and $m-\mathrm{Ph} \mathrm{CPh}_{3}$ ), 128.7 (s, aromatic $C \mathrm{H}, m-\mathrm{Ph}$ $\mathrm{CPh}_{3}$ ), 127.2 (s, aromatic $\mathrm{CH}, o$-Pipp), 127.1 (s, aromatic $C \mathrm{H}, m$ Pipp), $119.2\left(\mathrm{dd},{ }^{2} J_{\mathrm{C}-\mathrm{P}}=34.7 \mathrm{~Hz},{ }^{3} J_{\mathrm{C}-\mathrm{P}}=10.3 \mathrm{~Hz}\right.$, pyrrole $\left.C \mathrm{H}\right)$, 74.8 (s, $\left.\mathrm{Ph}_{3} \mathrm{CNH}\right), 33.9$ (s, $\left.\mathrm{CH}\left(\mathrm{CH}_{3}\right)_{2}\right), 24.5$, (s, $\left.\mathrm{CH}\left(\mathrm{CH}_{3}\right)_{2}\right)$. ${ }^{31} \mathrm{P}\left\{{ }^{1} \mathrm{H}\right\}$ NMR (benzene- $\left.d_{6}\right): \delta 25.0$.

LLu(NHCPh $)_{2}$ (4). In an argon atmosphere glove box, $\mathbf{L L u}\left(\mathrm{CH}_{2} \mathrm{SiMe}_{3}\right)_{2}(50.4 \mathrm{mg}, 0.0480 \mathrm{mmol})$ was weighed into a 20 $\mathrm{mL}$ scintillation vial and dissolved in $2 \mathrm{~mL}$ of toluene. $\mathrm{Ph}_{3} \mathrm{CNH}_{2}$ (26.2 $\mathrm{mg}, 0.101 \mathrm{mmol}$ ) was weighed into a vial and dissolved in 3 mL of toluene. The $\mathrm{Ph}_{3} \mathrm{CNH}_{2}$ solution was added dropwise over 5 minutes to the stirring solution of $\mathrm{LLu}\left(\mathrm{CH}_{2} \mathrm{SiMe}_{3}\right)_{2}$. The resulting colourless mixture was stirred for $22 \mathrm{~h}$ at ambient temperature at which point the volatiles were removed in vacuo to yield a pale yellow oil. This oil was triturated 2 times with $3 \mathrm{~mL}$ of pentane and dried in vacuo to yield a white powder $(52.2 \mathrm{mg}, 77 \%$ (crude)). An analytically pure sample was obtained by recrystallization from toluene/heptane (5:3) mixture at $-35{ }^{\circ} \mathrm{C}(6.81 \mathrm{mg}, 10 \%) .{ }^{1} \mathrm{H}$ NMR (benzene-d6): $\delta 7.54$ (ddd, ${ }^{3} J_{\mathrm{H}-\mathrm{P}}=20.1 \mathrm{~Hz},{ }^{3} J_{\mathrm{H}-\mathrm{H}}=7.8 \mathrm{~Hz},{ }^{4} J_{\mathrm{H}-\mathrm{H}}=$ $1.2 \mathrm{~Hz}, 8 \mathrm{H}, o$-phenyl $H$ ), 7.41-7.38 (ov m, $12 \mathrm{H}, m$ - and $p$ - phenyl $H$ ), 7.03-6.91 (30 H, $m$-, $p$ - and $o$-phenyl $\left.\mathrm{CPh}_{3} H\right), 6.78\left(\mathrm{dd},{ }^{3} J_{\mathrm{H}-\mathrm{H}}\right.$ $\left.=8.4 \mathrm{~Hz},{ }^{4} J_{\mathrm{H}-\mathrm{P}}=1.8 \mathrm{~Hz}, 4 \mathrm{H}, o-\operatorname{Pipp} H\right), 6.70\left(\mathrm{~d},{ }^{3} J_{\mathrm{H}-\mathrm{H}}=8.4 \mathrm{~Hz}\right.$, $m$-Pipp $H), 6.66\left(\mathrm{dd},{ }^{3} J_{\mathrm{H}-\mathrm{P}}=2.4 \mathrm{~Hz},{ }^{4} J_{\mathrm{H}-\mathrm{P}}=1.2 \mathrm{~Hz}, 2 \mathrm{H}\right.$, pyrrole $H$ ), $2.73\left(\mathrm{sp},{ }^{3} J_{\mathrm{H}-\mathrm{H}}=6.9 \mathrm{~Hz}, 2 \mathrm{H}, \mathrm{CH}\left(\mathrm{CH}_{3}\right)_{2}\right), 2.70(\mathrm{~s}, 2 \mathrm{H}, \mathrm{NH}), 1.18(\mathrm{~d}$, $\left.{ }^{3} J_{\mathrm{H}-\mathrm{H}}=6.9 \mathrm{~Hz}, 12 \mathrm{H}, \mathrm{CH}\left(\mathrm{CH}_{3}\right)_{2}\right) .{ }^{13} \mathrm{C}\left\{{ }^{1} \mathrm{H}\right\}$ NMR (benzene- $\left.d_{6}\right): \delta$ 154.4 (s, aromatic ipso- $\left.C, \mathrm{CPh}_{3}\right), 144.8\left(\mathrm{~d},{ }^{1} J_{\mathrm{C}-\mathrm{P}}=5.5 \mathrm{~Hz}\right)$ aromatic ipso- $C$, Pipp), 141.9 (s, aromatic ipso- $C, \mathrm{Ph}), 133.9\left(\mathrm{~d},{ }^{2} J_{\mathrm{C}-\mathrm{P}}=16.2\right.$ $\mathrm{Hz}$, aromatic $C \mathrm{H}, o-\mathrm{Ph}$ ), 132.6 (s, aromatic ipso- $C$, p-Pipp), 132.2 (s, aromatic $C \mathrm{H}, p-\mathrm{Ph}$ ), 131.4 (s, aromatic ipso- $C$, pyrrole), 129.8 (s, aromatic $C \mathrm{H}, o-\mathrm{Ph}, \mathrm{CPh}_{3}$ ), 129.0 (s, aromatic $C \mathrm{H}, p-\mathrm{Ph}, \mathrm{CPh}_{3}$ ), 128.7 (s, aromatic $C H, o$-Pipp), 127.9 (s, aromatic $C H, m-P h$, $\mathrm{CPh}_{3}$ ), 126.9 (s, aromatic $\mathrm{CH}, m$-Pipp), 125.8 (s, aromatic $\mathrm{CH}, m$ -
$\mathrm{Ph}), 119.2\left(\mathrm{dd},{ }^{2} J_{\mathrm{C}-\mathrm{P}}=27.6 \mathrm{~Hz},{ }^{3} J_{\mathrm{C}-\mathrm{P}}=11.5 \mathrm{~Hz}\right.$, pyrrole $\left.\mathrm{CH}\right), 75.1$ (s, $\left.\mathrm{Ph}_{3} \mathrm{CNH}\right), 34.0$ (s, $\left.\mathrm{CH}\left(\mathrm{CH}_{3}\right)_{2}\right), 24.7\left(\mathrm{~s}, \mathrm{CH}\left(\mathrm{CH}_{3}\right)_{2}\right) .{ }^{31} \mathrm{P}\left\{{ }^{1} \mathrm{H}\right\}$ NMR (benzene- $d_{6}$ ): $\delta 21.7$ (s). Anal. Calcd. (\%) for $\mathrm{C}_{85} \mathrm{H}_{80} \mathrm{LuN}_{5} \mathrm{P}_{2}$ : C, 72.48; H, 5.72; N, 4.97. Found: C, 71.77; H, 5.80; N, 4.54 .

General DMAP Studies. An NMR tube was charged with complex $2(0.0062 \mathrm{~g}, 0.0050 \mathrm{mmol})$ and the desired stoichiometry of 4dimethylaminopyridine $\left(0.5,1,2\right.$, or 4 equivalents). Benzene- $d_{6}$ was added to the NMR tube and sealed with a rubber septum. The mixture was shaken to dissolve all reagents and placed into an 80 ${ }^{\circ} \mathrm{C}$ oil bath. The reaction was heated for 24 hours at which point the product distribution was determined by ${ }^{31} \mathrm{P}\left\{{ }^{1} \mathrm{H}\right\}$ and ${ }^{1} \mathrm{H}$ NMR spectroscopy.

NMR Kinetics. The rate constant $k_{l}$ was determined by monitoring ${ }^{31} \mathrm{P}\left\{{ }^{1} \mathrm{H}\right\}$ NMR resonances over at least 3 half lives at a given temperature. In a typical experiment complex $\mathbf{2} / \mathbf{2}-\boldsymbol{d}_{\mathbf{1}}(0.0185 \mathrm{~g}, 0.0151$ mmol) was added into an NMR tube charged with an internal $\mathrm{H}_{3} \mathrm{PO}_{4}$ standard. Toluene- $d_{8}(0.55 \mathrm{~mL})$ was added to the tube and sealed with a rubber septum. The mixture was shaken to dissolve all reagents and then immediately placed in a dry ice bath $\left(-78^{\circ} \mathrm{C}\right)$. This tube was added into the NMR probe which had been pre-equilibrated to the desired temperature. The sample equilibrated to this temperature over the course of shimming the probe. ${ }^{31} \mathrm{P}\left\{{ }^{1} \mathrm{H}\right\}$ spectra were recorded at specific time intervals until the reaction had progressed to at least 3 half lives. The extent of reaction at each time interval was determined by integration of the peak intensity relative to that of the $\mathrm{H}_{3} \mathrm{PO}_{4}$ standard. An appropriately long delay between scans was utilized to ensure that integration was quantitative and not effected by $\mathrm{T}_{1}$ relaxation times. The observed rate constant $k_{1}$ (obsd) was determined according to the law of mass action.

Diffusion Experiments. Diffusion measurements were performed using a Bruker Avance III HD $700 \mathrm{MHz}$ spectrometer equipped with a gradient controller and a TXO probe with automatic tuning and a shielded z-gradient. The gradient shape was sinusoidal and its length was $1.8 \mathrm{~ms}$. The gradient strength was increased by 16 increments of $6.2 \%(2 \%-95 \%)$. The time between the midpoints of these gradients was $99.97 \mathrm{~ms}$. Experiments were performed at $292 \mathrm{~K}$ within the NMR probe.

\section{X-ray crystallography}

Single crystals of complex 4 were obtained over 24 hours from a toluene/heptane (5:3) solution of $\mathbf{4}$ at $-35^{\circ} \mathrm{C}$. Crystals were coated in dry Paratone oil under an argon atmosphere and mounted onto a MiTeGen microloop. Data were collected at $173 \mathrm{~K}$ using a Bruker SMART APEX II diffractometer (Mo K $\alpha$ radiation, $\lambda=0.71073 \AA$ ) outfitted with a CCD area-detector and a KRYO-FLEX liquid nitrogen vapour cooling device. A data collection strategy using $\omega$ and $\varphi$ scans at $0.5^{\circ}$ steps yielded full hemispherical data with excellent intensity statistics. Unit cell parameters were determined and refined on all observed reflections using APEX2 software. ${ }^{19}$ Data reduction and correction for Lorentz polarization were performed using SAINT-Plus software. ${ }^{20}$ Absorption corrections were applied using SADABS. ${ }^{22}$ The structures were solved by direct methods and refined by the least squares method on $F^{2}$ using the SHELX software suite ${ }^{22}$ using the Olex 2 program. ${ }^{23}$ All non-hydrogen atoms were refined anisotropically. $\mathrm{C}-\mathrm{H}$ hydrogen atom positions were calculated and isotropically refined as riding models to their parent atoms, whereas $\mathrm{N}-\mathrm{H}$ hydrogens were located from the Fourier difference maps and isotropically refined with a fixed $\mathrm{N}-\mathrm{H}$ bond length. A summary of selected data collection and refinement parameters is presented below.

Crystal Data for 4: $\mathrm{C}_{91} \mathrm{H}_{84} \mathrm{LuN}_{5} \mathrm{P}_{2}(M=1484.54 \mathrm{~g} / \mathrm{mol})$ : triclinic, space group $P-1$ (no. 2), $a=12.314(2) \AA, b=13.648(2) \AA, c=$ 23.195(4) $\AA, \alpha=\quad 97.8241(18)^{\circ}, \beta=\quad 99.3181(17)^{\circ}, \gamma=$ $106.8141(17)^{\circ}, V=3612.7(10) \AA^{3}, Z=2, T=173 \mathrm{~K}, \mu(\mathrm{MoK} \alpha)=$ $1.462 \mathrm{~mm}^{-1}, D_{\text {calc }}=1.365 \mathrm{~g} / \mathrm{cm}^{3}, 38497$ reflections measured $\left(3.178^{\circ} \leq 2 \Theta \leq 50^{\circ}\right), 12722$ unique $\left(R_{\text {int }}=0.0658, R_{\text {sigma }}=0.0752\right)$ 
which were used in all calculations. The final $R_{1}$ was 0.0380 (I > $2 \sigma(\mathrm{I}))$ and $w R_{2}$ was 0.0819 (all data)

\section{Computational details}

The geometry optimizations and full vibration analysis of all studied complexes were performed using the Gaussian 09 program package. ${ }^{24}$ The PBE1PBE ${ }^{25}$ hybrid functional and SVP ${ }^{26 a}$ or def2TZVP26b-c basis sets by Ahlrichs et al. were used in all optimizations and frequency calculations. For Lu, a small-core SDD pseudopotential by Cao and Dolg was used. ${ }^{27}$

\section{Appendix A. Supplementary Data}

$\mathrm{X}$-ray crystallographic details in CIF format, bond lengths and angles for $\mathbf{4}$ in PDF format, NMR spectra of 2, 3, and $\mathbf{4}$ in PDF format, and $x y z$ coordinates of the geometry optimized complexes can be found in the supporting information.

\section{AUTHOR INFORMATION}

\section{Corresponding Author}

*E-mail: p.hayes@uleth.ca

\section{ACKNOWLEDGMENT}

This research was generously supported by the Natural Sciences and Engineering Research Council (NSERC) of Canada, the Canada Foundation for Innovation (CFI), the Academy of Finland and the University of Jyyäskylä. Mr. Tony Montina is acknowledged for expert technical assistance.

\section{REFERENCES}

1. (a) Mindiola, D. J. Acc. Chem. Res. 2006, 39, 813; (b) Scott, J.; Mindiola, D. J. Dalton Trans. 2009, 8463; (c) Gianetti, T. L.; La Pierre, H. S.; Arnold, J. Eur. J. Inorg. Chem. 2013, 3783; (d) Hayton, T. W. Dalton Trans. 2010, 39, 1145; (e) Mao, W.; Xiang, L.; Chen. Y. Chem. Rev. 2016, ASAP. (DOI:10.1016/j.ccr.2016.12.007)

2. Summerscales, O. T.; Gordon, J. C. RSC Advances 2013, 3, 6682 .

3. Beetstra, D. J.; Meetsma, A.; Hessen, B.; Teuben, J. H Organometallics 2003, 22, 4372.

4. $\quad$ Scott, J.; Basuli, F.; Fout, A. R.; Huffman, J. C.; Mindiola, D. J. Angew. Chem. Int. Ed. 2008, 47, 8502.

5. (a) Wicker, B. F.; Fan, H.; Hickey, A. K.; Crestani, M. G.; Scott, J.; Pink, M.; Mindiola, D. J. J. Am. Chem. Soc. 2012, 134, 20081; (b) Wicker, B. F.; Scott, J.; Fout, A. R.; Pink, M.; Mindiola, D. J. Organometallics 2011, 30, 2453.

6. Lu, E.; Li, Y.; Chen, Y. Chem. Commun. 2010, 46, 4469

7. (a) Lu, E.; Chu, J.; Chen, Y.; Borzov, M. V.; Li, G. Chem. Commun. 2010, 47, 743; (b) Chu, J.; Lu, E.; Liu, Z.; Chen, Y.; Leng, X.; Song, H. Angew. Chem. Int. Ed. 2011, 50, 7677; (c) Lu, E.; Zhou, Q.; Li, Y.; Chu, J.; Chen, Y.; Leng, X.; Sun, J. Chem. Commun. 2012, 48, 3403; (d) Rong, W.; Cheng, J.; Mou, Z.; Xie, H.; Cui, D. Organometallics 2013, 32, 5523; (e) Chu, T.; Piers, W. E.; Dutton, J. L.; Parvez, M. Organometallics 2013, 32, 1159; (f) Jian, Z.; Rong, W.; Mou, Z.; Pan, Y.; Xie, H.; Cui, D. Chem. Commun. 2012, 48, 7516; (g) Chu, J.; Kefalidis, C. E.; Maron, L.; Leng, X.; Chen, Y. J. Am. Chem. Soc. 2013, 135, 8165; (h) Lu, E.; Chu, J.; Chen, Y.; Borzov, M. V.; Li, G. Chem. Commun. 2011, 47, 743; (i) Chu, J.; Lu, E.; Chen, Y.; Leng, X. Organometallics 2013, 32, 1137; (j) Chu, J.;
Han, X.; Kefalidis, C. E.; Zhou, J.; Maron, L.; Leng, X.; Chen, Y. J. Am. Chem. Soc. 2014, 136, 10894.

Knight, L. K.; Piers, W. E.; Fleurat-Lessard, P.; Parvez, M.; McDonald, R. Organometallics 2004, 23, 2087.

9. Schadle, D.; Meermann-Zimmermann, M.; Schadle, C.; Maichle-Moessmer, C.; Anwander, R., Eur. J. Inorg. Chem. 2015, 1334.

10. Johnson, K. R. D.; Hannon, M. A.; Ritch, J. S.; Hayes, P. G. Dalton Trans. 2012, 41, 7873.

11. Zamora, M. T.; Johnson, K. R. D.; Hänninen, M. M.; Hayes, P. G. Dalton Trans. 2014, 43, 10739.

12. Johnson, K. R. D.; Hayes, P. G. Organometallics 2009, 28, 6352.

13. Johnson, K. R. D.; Hayes, P. G. Organometallics 2011, $30,58$.

14. (a) Liu, B.; Liu, X.; Cui, D.; Liu, L. Organometallics 2009, 28 1453; (b) Petrov, A. R.; Thomas, O.; Harms, K.; Rufanov, K. A.; Sundermeyer, J. J. Organomet. Chem. 2010, 695, 2738; (c) Hillesheim, Nina S.; Elfferding, M.; Linder, T.; Sundermeyer, J. Z. Anorg. Allg. Chem. 2010, 636, 1776.

15. (a) Schädle, D.; Maichle-Mössmer, C.; Schädle, C.; Anwander, R. Chem. Eur. J. 2015, 21, 662; (b) CSD database (version 5.38) search resulting in $18 \mathrm{Lu}-\mathrm{NHAr}$ mononuclear structures.

16. (a) Rufanov, K. A.; Müller, B. H.; Spannenberg, A.; Rosenthal, U. New J. Chem. 2006, 30, 29; (b) Liu, B.; Liu, X.; Cui, D.; Liu, L. Organometallics 2009, 28, 1543.; (c) Liu, B.; Cui, D.; Ma, J.; Chen, X.; Jing, X. Chem. Eur. J. 2007, 13, 834.

17. (a) Rufanov, K. A.; Muller, B. H.; Spannenberg, A.; Rosenthal, U. New J. Chem. 2006, 30, 29; (b) Liu, B.; Cui, D.; Ma, J.; Chen, X.; Jing, X. Chem. Eur. J. 2007, 13, 834.

18. (a) Johnson, K. R. D.; Hannon, M. A.; Ritch, J. S.; Hayes, P. G., Dalton Trans. 2012, 41, 7873-7875; (b) Estler, F.; Eickerling, G.; Herdtweck, E.; Anwander, R. Organometallics 2003, 22, 1212.

19. $A P E X 2$, Bruker AXS: Madison, WI, 2010.

20. SAINT-Plus, version 7.23a; Bruker AXS: Madison, WI, 2009

22. Sheldrick, G. M. SADABS, version 2004/1; Bruker AXS: Madison, WI, 2008.

22. Sheldrick, G. M., Acta Crystallogr A 2008, 64 (Pt 1), 112.

23. Dolomanov, O. V.; Bourhis, J.; Gildea, R. J.; Howard, J. A. K.; Puschmann, H. J. Appl. Cryst. 2009, 42, 339.

24. Frisch, M. J.; Trucks, G. W.; Schlegel, H. B.; Scuseria, G. E.; Robb, M. A.; Cheeseman, J. R.; Scalmani, G.; Barone, V.; Mennucci, B.; Petersson, G. A.; Nakatsuji, H.; Caricato, M.; Li, X.; Hratchian, H. P.; Izmaylov, A. F.; Bloino, J.; Zheng, G.; Sonnenberg, J. L.; Hada, M.; Ehara, M.; Toyota, K.; Fukuda, R.; Hasegawa, J.; Ishida, M.; Nakajima, T.; Honda, Y.; Kitao, O.; Nakai, H.; Vreven, T.; Jr; Peralta, J. E.; Ogliaro, F.; Bearpark, M.; Heyd, J. J.; Brothers, E.; Kudin, K. N.; Staroverov, V. N.; Kobayashi, R.; Normand, J.; Raghavachari, K.; Rendell, A.; Burant, J. C.; Iyengar, S. S.; Tomasi, J.; Cossi, M.; Rega, N.; Millam, J. M.; Klene, M.; Knox, J. E.; Cross, J. B.; Bakken, V.; Adamo, C.; Jaramillo, J.; Gomperts, R.; Stratmann, R. E.; Yazyev, O.; Austin, A. J.; Cammi, R.; Pomelli, C.; Ochterski, J. W.; Martin, R. L.; Morokuma, K.; Zakrzewski, V. G.; Voth, G. A.; Salvador, P.; Dannenberg, J. J.; Dapprich, S.; Daniels, A. D.; Farkas; Foresman, J. B.; Ortiz, J. V.; Cioslowski, J.; Fox, D. J., Gaussian 09 Revision D.01. Gaussian Inc. : Wallingford CT, 2009.

25. (a) Perdew, J. P.; Burke, K.; Ernzerhof, M. Phys. Rev. Lett. 1996, 77, 3865; (b) Perdew, J. P.; Burke, K.; Ernzerhof, M. Phys. Rev. Lett. 1997, 78, 1396; (c) Adamo, C.; Barone, V. J. Chem. Phys. 1999, 110, 6158.

26. (a) Schäfer, A.; Horn, H.; Ahlrichs, R. J. Chem. Phys. 1992, 97, 2571; (b) Weigend, F.; Häser, M.; Patzelt, H.; Ahlrichs, R. Chem. Phys. Lett. 1998, 294, 143; (c) Weigend, F.; Ahlrichs, R. PCCP 2005, 7, 3297.

27. Cao, X.; Dolg, M. J. Chem. Phys. 2001, 115, 7348. 